\title{
CUSTOMER PERCEPTION ON SERVICE QUALITY TOWARDS TOURISM CUSTOMER SATISFACTION IN MALAYSIAN MARINE TOURISM SECTOR
}

\author{
Mohammad Arije ULFY \\ International Islamic University Malaysia, Department of Business Administration, \\ Jalan Gombak, Kuala Lumpur, Malaysia, e-mail: md.arije@ hotmail.com \\ Md Suliman HOSSIN* \\ University Kuala Lumpur, UniKL Business School, Malaysia, e-mail: md.suliman@s.unikl.edu.my \\ Md Wasiul KARIM \\ International Islamic University Malaysia, Department of Business Administration, \\ Jalan Gombak, Kuala Lumpur, Malaysia, e-mail: wasiul45@gmail.com \\ Fatin Husna Binti SUIB \\ International Islamic University Malaysia, Department of Business Administration, \\ Jalan Gombak, Kuala Lumpur, Malaysia, e-mail: fatinhusnasuib@iium.edu.my
}

\begin{abstract}
Citation: Ulfy, M.A., Hossin, M.S., Karim, M.W., \& Suib, F.H.B. (2021). CUSTOMER PERCEPTION ON SERVICE QUALITY TOWARDS TOURISM CUSTOMER SATISFACTION IN MALAYSIAN MARINE TOURISM SECTOR. GeoJournal of Tourism and Geosites, 37(3), 792-799. https://doi.org/10.30892/gtg.37308-710
\end{abstract}

\begin{abstract}
Marine based tourism has emerged as a subject of concern in the area of ocean and coastal management. Today, demand for marine tourism has increased dramatically and is highlighted as one of the new horizons and fastest-growing sectors in the world's tourism industry. Malaysia is indeed one of the countries with the most beautiful and diversified marine life. The fundamental purpose of this study is to examine the satisfaction of tourists towards the service quality of marine tourism in Malaysia. The development of the research framework is based on the SERVQUAL model. A total of 300 responses were received from the Klang Valley area of Malaysia. For the purpose of processing and analyzing the data, Partial Least Square (PLS-SEM) method was employed. By applying a two-step approach, the study assesses the measurement model and the structural model. Findings from the survey reveal that assurance, tangibility, empathy, reliability, and responsiveness have a significant positive relationship with customer satisfaction thus these factors describe the customer satisfaction adequately. This study would enable policymakers and tourism companies to develop policies to improve customer satisfaction by increasing the quality of service.
\end{abstract}

Key words: Customer Perception, Marine Tourism, Malaysia, PLS-SEM, Satisfaction, SERVQUAL

$* * * * * *$

\section{INTRODUCTION}

Marine tourism applies to land-based tourism activities like sailing, surfing, sunbathing and other marine leisure activities on coastal regions where the closeness to the sea is a requirement and their facilities (Cao, 2020). Maritime tourism refers to maritime activities such as Surfing, paragliding, snorkelling, scuba diving, boating, yachting, fishing, nautical sports, as well as services and infrastructure based on land (Western Mediterranean Ecoregion, 2019). Nowadays marine tourism is one of the most attractive and sensational domestic and foreign tourism industries that many countries are looking to develop and improve (Rogerson et al., 2018). Therefore, Sea tours, water sports, diving, and other beach and offshore activities are all in marine tourism (Bhuiyan et al., 2020). The number of marine tourists is increasing every year as cruise passengers, and many countries, both small and large, are trying to make the most of their smallest water, sea and coastal capacities to maximize their income by attracting travellers (Hall, 2001).

In addition, maritime tourism sector interrelated and created strong linkages to land-based tourism events such as sailing, sightseeing, sunbathing, and other recreational activities on the beach that include the proximity to the sea, and related services (Bin et al., 2020). Offshore activities such as fishing, sailing, cruising, marine sports and their facilities and land infrastructure improve maritime tourism (Papageorgiou, 2016).

Thus, Malaysian marine tourism is considered one of the greatest extensive tourism industries (Jones and Syura, 2020). Several studies associated with customer satisfaction levels on marine tourism have been conducted over several years (Brown, 2013; Ostheimer, 2012; Wonderful Malaysia, 2014). In present-day argument on the feature of marine tourism services, one of the highest concerns was whether tourists were satisfied with the service quality in Malaysian marine tourism sector, of the delivery process on provided facilities towards tourist's desires (Bin et al., 2020). To develop Malaysian marine tourism, it becomes crucial to deliberate tourist perception so that service quality will satisfy tourist satisfaction with a tourist needs in a regular way (Jones and Syura, 2020). Tourist satisfaction can be gained by the concern

\footnotetext{
* Corresponding author
} 
authorities with their various quality assistance. Aimed at intentional planning determinations of the marine tourism sectors, those benefits can be included as a measurement. Understanding customer's reaction to marine tourism products and services, promising both new and recurrence visitors that defines areas need to improve (Ibrahim and Ahmad, 2008).

In addition, inadequate evidence has been existing on the term of service quality and visitors pleasure points in marine tourism sector of Malaysia (Cao, 2020). Furthermore, the present research considers on service quality as there is no efforts associated to all the possible aspects of the service quality in one shot to inspect potentials and observations of travellers' satisfaction stages that could disclose a substantial hole of facts. Additionally, several of the previous research are obsolete and so fresh research are required in place they could conduct diverse outcomes, witnessing the substantial progress of marine-tourism sector in Malaysia (Rogerson, 2020). For the gap fulfilment, this study scrutinises the opportunities and observations of travellers on service quality and relates to their viewpoint of satisfaction echelons.

Customer satisfaction in the marine tourism segment is based on quite a few aspects, such as strategic improvement, public transportation efficiency, government policies, coastal entertaining facilities, accommodation, information centre, food and beverage services and so on (Hall, 2001). Nevertheless, rendering to (Ibrahim and Ahmad, 2008) the constant growth of marine tourism affects the influences on structural development and good quality facilities to the customers. Besides, any upgrading in the sector must consider a complete tactic since any deficit in any one of the areas could collapse and impair a then delightful involvement for the travellers. Therefore, the facility providing authority should be concerned of attaining and continuing a constant side by side assistance to ensure better service quality, equally in their travel offerings and scheme of services. Therefore, by studying customer satisfaction in marine tourism, management can identify factors that can help improve the services provided to increase customer satisfaction in tourism and thus increase frequent visits (Lam-González et al., 2019). Much of previous research also included service quality on customer satisfaction as well as tourism development (Rogerson, 2020).

The realistic purpose of this article is to help identify the dimensions service providers can consider when designing a marine tourism service quality assessment. Specifically, we will attempt to explain the definition of the SERVQUAL model (Parasuraman et al., 1988) with the factors (i.e. tangibility, reliability, responsiveness, and assurance, empathy) in terms of marine tourism service and its relevance to tourists and to recognize issues related to specific services from various studies. The proposed improved service quality evaluation model can also serve as a useful tool for assessing longstanding interactions with tourists and thereafter growing maritime tourism satisfaction.

\section{LITERATURE REVIEW}

\section{Service Quality and Marine Tourism Customer Satisfaction}

Quality is characterized as the substance of a commodity or service's functionality and specifications which depend on its capacity to fulfil specific desires (Latif and Imm, 2015). "Endurance in order" is the modern definition of consistency. This definition moves the quality measurement from the service provider to the customer. Furthermore, to be of high-quality service, the marine tourism service provider must be mindful of the views and experiences of the traveller (Jones and Syura, 2020). Likewise, many scholars agreed mostly with contemporary quality definition. According to Owen et al. (1995), quality is described as serving customers' expectations. Oakland (1989) has mentioned quality is represented as the 'simply satisfying' standard. Juran (1979) describes quality as 'a prerequisite for a commodity that responds to the demands of certain community consumers who are actually using it. It is a basic definition of quality.

Quality is the generic phrase for usage satisfaction, and the simple meaning is that quality implies usage satisfaction. The scholars therefore argue that the ultimate objective of quality is to please clients where the quality of their services is an absolutely vital element of the satisfaction of maritime tourism clients (Ibrahim and Ahmad, 2008). Marine quality goods or services should be able to accomplish their customers' expectations or demands through those attributes or criteria. Besides that, certain prerequisites are unique and diverse from each client so that service providers are faced with the difficulty of understanding the needs of true marine tourism customers and of incorporating those requirements into products or services which satisfy such necessities (Zakaria et al., 2010).

For service providers like marine tourism operators, service qualities are significant as the assessment of service quality and the degree of satisfaction that results is intended to decide the probability of revisit and highly affect the underlying operations performance measurement (Iacobucci, 2010). In addition, satisfaction or disappointment can be anticipated in contributing to the satisfaction of the customer and the ability to sustain a long-term relationship with the tourism service provider (Athanassopoulos et al., 2001). For managers to understand what service quality is, and how it can be described to please marine tourists, it is therefore critical that it be measured (Rogerson, 2020). In order to enhance the efficiency, supervision is incredibly useful in a simple understanding of efficiency. It has to be consciously handled in the marine tourism sector to build a facility that could be used as a competitive instrument. In the end, excellently managed standard of service guarantees the satisfaction of clients in marine tourism (Hall, 2001). Moreover, Sureshchandar et al. (2002) argue that 'customer satisfaction can be achieved at various levels both inside and beyond the company,' for instance 'contact person, key facility or the entire organization' (Sureschandar et al. 2002). Extremely good quality of service is however considered to be a significant success factor impacting the productivity of organisations. Furthermore, the quality of the marine tourist service is considered as a key determinant for tourist's perception analysis (Gounaris and Dimitriadis, 2003).

As a result of poor service, many tourism companies have made substantial efforts to ensure that their facilities are of high quality in order to be able to distinguish themselves from their opponents (Ibrahim and Ahmad, 2008). Quality of products or services will draw both frequent visiting and new clients in the maritime tourism industry. Service levels are harder to stabilise as consumers in tourism have become more attentive to quality, according to Augustyn and Ho (1998). 
They further establish that the emphasis has changed from recognisable goods to a more versatile approach to a higher quality consumer. Moreover, the issue of evaluating satisfaction of marine tourism can also represent an enormous challenge. Pawitra and Tan (2003) noted that marine tourism is clearly a different activity phenomenon in fishing, sailing, cruising, maritime and coastal entertainment. Tourist satisfaction of a maritime sector is complex, it is inflated by familiarities from numerous regional tourism associated service providers (Zakaria et al., 2010).

In marine tourism sector tangibility encompasses external, inward services, boating, yachting, fishing, nautical sports which are significantly related to marine tourism customer satisfaction (Western Mediterranean Ecoregion, 2019); although, Santos (2002) stated accommodation, technical structures, utilities, facilities, external manpower capacity, contact materials and other physical functionalities in use by companies for the provision and distribution of utilities are visible to marine tourists. Berry et al. (1994) claimed that reliability is an essential component and it has been endorsed that reliability would persist one of main components in tourism segment, despite of the categories of other sectors. Daskalakis and Stathopoulos (2008) described that reliability emphasizes on decreasing traveling duration along with shortening the variance in journey moment because such variance can lead to ambiguity of travel period (Tse and Wilton, 1988). Reliability of maritime tourism was identified to be closely associated towards comfort level and fulfilment rates in additional services (Zhi-Gang and Xiao-Dong, 2013). Reliability could include service provider behaviours and serving mind-set prior to serve in marine tourism sector as a vital component to determine tourist's satisfaction.

Responsiveness has been described by workforce commitment or even capacity information service (Allred and Addams, 2000). Perception of staff tendency to react correctly, and workers 'efficiency and pace for entertaining marine tourism customers could be detected throughout this context (Bartlett and Han, 2007). Compassion of service provider practical responsiveness, providing coastal entertainment service with resources and planning of entertainment schedule are positively related to marine tourism customer satisfaction (Zhi-Gang and Xiao-Dong, 2013).

As for the assurance, it's been described as staff 'expertise and decency in their capacity to inculcate faith and trust to (Parasuraman et al., 1988). Vogel and Pettinari (2002), mentioned that for tourist's satisfaction, travel companies should assure the customers feel of comfortable when patronizing marine tourism facilities, as this will contribute to increase mutual trust in staff and marine travel operators among tourists. Zhi-Gang and Xiao-Dong (2013) described, contact language was considered one of the biggest assurance components, in addition to components such as travel information, existence of security services, minor adjustments and vouchers. Empathy was described as the ability of mental position to oneself in certain condition and problems statement of one another, and the capacity to consider the individual's psychological and personal viewpoint (Varca, 2004). According to Anderson and Fornell (1994), it is claimed that empathy includes the needs and expectations of customers, as well as providing service with personal consideration. This is an inner awareness that will progress towards better ability to identify tourists' intangible positive attributes (Latif and IIM, 2015).

The current discussion mentions and suggests that service quality and customer satisfaction are ambiguous phenomena and are several components associated with marine tourism customer satisfaction. As executives, their key preoccupation is to establish and develop trust within their focused tourists (Latiff and Imm, 2015). It can also be accomplished by enhancing the standard of service being one of the widely common models for analyzing satisfaction in marine tourism sector (Zakaria et al., 2010), SERVQUAL is often utilized within the tourism sector to evaluate the satisfaction of a venue for tourists (Pawitra and Tan, 2003). The SERVQUAL model discussed by (Parasuraman et al., 1988 ) is indeed a measure of 22 objects, comparing consumer expectations and satisfaction throughout five scales. Even though the SERVQUAL method was severely questioned by certain researchers for few driving factors, due of the capability to estimate service quality in specific sector like marine tourism, the SERVQUAL determinants are commonly used to measure customer satisfaction in tourism sector (Latif and IIM, 2015).

\section{Hypothesis Development}

Furthermore, the method is often used as a basis for assessing the quality-of-service performance from the point of view of the customer. Therefore, also we formed the preceding hypotheses to test this:

Table 1. Hypothesis Development

\begin{tabular}{|c|l|}
\hline HYPOTHESIS & \multicolumn{1}{c|}{ DESCRIPTION } \\
\hline $\mathbf{H}_{\mathbf{1}}$ & Marine tourism service providers were capable to achieve tangible marine tourism customer satisfaction standard \\
\hline $\mathbf{H}_{\mathbf{2}}$ & Marine tourism service providers were capable to achieve reliable marine tourism customer satisfaction standard \\
\hline $\mathbf{H}_{\mathbf{3}}$ & Marine tourism service providers were capable to achieve responsive marine tourism customer satisfaction standard \\
\hline $\mathbf{H}_{\mathbf{4}}$ & Marine tourism service providers were capable to achieve marine tourism customer satisfaction standard (In terms of assurance) \\
\hline $\mathbf{H}_{\mathbf{5}}$ & Marine tourism service providers were capable to achieve marine tourism customer satisfaction standard (In terms of empathy) \\
\hline
\end{tabular}

\section{THEORETICAL FRAMEWORK}

Many works of literature are concentrating on the service quality assessment of tourism service providers (Latiff and Imm, 2015; Zakaria et al., 2010; Pawitra and Tan, 2003). There is a deficiency of research concentrating on how to form a perfect service quality assessment framework for marine tourism service providers as marine tourism is becoming popular day by day mainly in developing countries. As a result, through an extensive literature review, we have undertaken present cognitive research of Malaysian marine-tourism service and achieve measurement parameters from the existing SERVQUAL models (Parasuraman et al., 1988) provide a suitable method for quantifying the efficiency of the Marine Tourism services. Service quality including ten dimensions has been proposed in the beginning by Parasuraman et al. (1985), as follows: 
Table 2. SERVQUAL dimensions' description (Note: SERVQUAL = service quality)

\begin{tabular}{|l|l|l|}
\hline Tangibility & $:$ & Accommodation, equipment, staff uniforms, toilets, vehicles and so on. \\
\hline Reliability & $:$ & Employees 'capacity to deliver the expected service with reliability and accuracy. \\
\hline Competence & $:$ & Employee capacity to support clients in an accommodating, secure and productive manner. \\
\hline Courtesy & $:$ & The willingness of the individual to conduct the function relates to staff. \\
\hline Credibility & $:$ & The interest, generosity of spirit and decency of workers towards their customers. \\
\hline Security & $:$ & The service's capacity to remove uncertainties, financial risks and physiological threat. \\
\hline Access & $:$ & To provide the customer and the service provider with connectivity. \\
\hline Communication & $:$ & Willingness of the supplier to efficiently communicate material and the terminology the service provider uses \\
\hline Understanding Customer & $:$ & The service provider demonstrated an interest in knowing \& respecting their consumer. \\
\hline
\end{tabular}

SERVQUAL New Dimension contained as mentioned below three original and two integrated scales. Such five variables of service quality are the main measures for evaluating marine tourists 'perception and satisfaction of the services rendered by the different tourism firms functioning well into the Klang Valley. The preceding categories and coherent explanations for the five components were proposed by Parasuraman et al. (1988),

\section{RESEARCH METHODOLOGY}

\section{Measurement Framework}

All the 20 items pertaining to the SERVQUAL dimensions were used in its original forms as proposed by Parasuraman et al. (1988) and 5 more items were used to explain the Malaysian marine tourism customer services. The decision to use the items in its original forms was reached since the main objective of the study is to gauge the general perceptions and expectations of tourists regarding the service quality delivered by the many businesses operating at Klang Valley. In addition, each item of the SERVQUAL dimensions were arranged according to five areas of service offered at marine tourism sector. A total of 8 variables were measured and respondents were asked to answer them based on a 5-point Likert scale $(1=$ Strongly Disagree; 5 = Strongly Agree). All the items of the questionnaire were designed using English language only.

Tangibility: Physical services, infrastructure, equipment and the workers presence.

Reliability: Quality to conduct the service offered with reliability as well as accuracy.

Responsiveness: Tendency to assist clients and deliver timely support. Assurance: Employee awareness and hospitality, and their ability to persuade faith and trust.

Empathy: The company provides personalized attention to the clients.

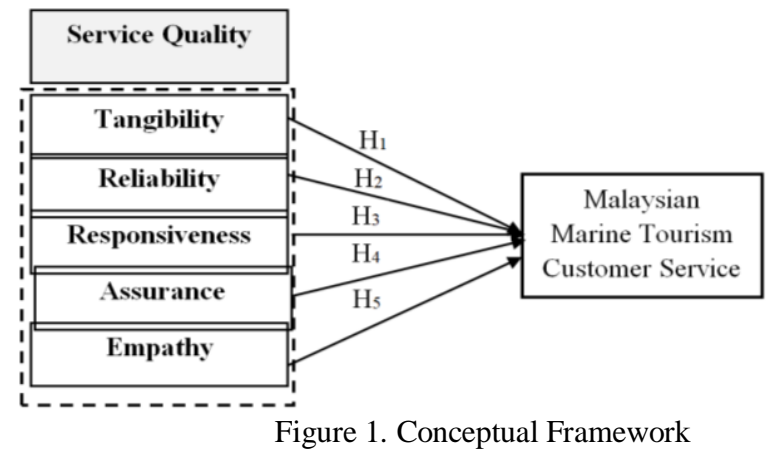

Table 3. Demographic Profile

\begin{tabular}{|c|l|c|c|}
\hline Measure & \multicolumn{1}{|c|}{ Item } & Frequency & Percentage \\
\hline \multirow{4}{*}{ Gender } & Male & 62 & 26.6 \\
\cline { 2 - 4 } & Female & 171 & 73.4 \\
\hline \multirow{5}{*}{ Age } & $15-24$ & 4 & 1.7 \\
\cline { 2 - 4 } & $25-34$ & 107 & 45.9 \\
\cline { 2 - 4 } & $35-44$ & 75 & 32.2 \\
\cline { 2 - 4 } & $45-54$ & 39 & 16.7 \\
\cline { 2 - 4 } & 55 and above & 8 & 3.4 \\
\hline \multirow{5}{*}{ Education } & Local & 70 & 30 \\
\cline { 2 - 4 } & Foreigner & 163 & 70 \\
\cline { 2 - 4 } & SPM/SSC & 116 & 49.8 \\
\cline { 2 - 4 } & STPM/HSC & 24 & 10.3 \\
\cline { 2 - 4 } & Diploma & 69 & 29.6 \\
\cline { 2 - 4 } & Undergraduate & 22 & 9.4 \\
\cline { 2 - 4 } & Postgraduate & 2 & .9 \\
\hline \multirow{5}{*}{ Occupation } & Student & 125 & 53.6 \\
\cline { 2 - 4 } & Private Service & 63 & 27.0 \\
\cline { 2 - 4 } & Business & 17 & 7.3 \\
\cline { 2 - 4 } & Government Service & 7 & 3.0 \\
\cline { 2 - 4 } & Others & 21 & 9.0 \\
\hline
\end{tabular}

\section{Data Collection}

This research is a descriptive study using survey sampling as its main research method to gain information on the service delivery systems of agencies and companies operating and providing services to tourists at Klang valley, Malaysia. The tourists are those who have spent at least 24 hours at Klang Valley. They were selected using sample random sampling. Tourists were given a set of questionnaires that would reveal their expectation before receiving the services provided by the various business establishments (service providers) and their perception of the actual services received from the service providers. Moreover, data were collected using online survey and paper-based questionnaire during the period of January - March 2020. A number of 330 responses were collected from whatsapp and facebook by sending the link of Google form and face-to-face conversation. 300 data were finally selected for analysis. Previous research recommends that a sample size of 100 to 200 is typically a good set up point in carrying out path modelling (Hoyle, 1995). Hence, for this study 300 responses were considered as good number to analyze and test the hypothesis.

\section{DATA ANALYSIS AND FINDINGS}

\section{Tools Used}

To analyze the demographic profile, SPSS version 24.0 was used; besides this, to validate the measurement and structural model, Smart PLS software version 3.0 was employed. 


\section{Demographic Profile}

Demographic data in Table 3 illustrates the responses collected from tourists who visited the Klang Valley area. The total distributed questionnaire was 300; however, after removing 32 missing values, a total of 268 data were kept for further analysis. Hence 35 outliers were detected by Mahalanobis Distance (MD); after removing the outliers a total of 233 valid data were used for the final report. The valid responses were $89.33 \%$ of the total distributed questionnaires. Table 3 shows that females responded more than males. $171(73.4 \%)$ of the respondents were female, and $62(26.6 \%)$ were male. The majority age was 25 to 34 years old (45.90\%), followed by the age of $35-44(32.20 \%), 45-54$ years old (16.70\%), 55 years above were (3.40\%), and lowest age group was $15-24$ years old $(1.70 \%)$. Among these respondents, $70 \%$ of tourists are foreigners, and the rest are local. Additionally, most of the respondents' educational qualification was SPM/SSC (49.80\%), followed by a diploma (29.60\%), STPM/HSC (10.30\%), Undergraduate (9.40\%) and Postgraduates were (.90\%). Furthermore, respondents were asked about their occupation, $(53.60 \%)$ were students followed by private services $(27.0 \%)$, and Business personnel was $(7.30 \%)$, and rest is others $(9.0 \%)$.

\section{Measurement Model}

Convergent and Discriminant validity tests were performed to assess the measurement model. To test the convergent validity, each construct's value (CR and $\boldsymbol{\alpha}$ ) should be higher than 0.708 (Hair et al., 2016). This study shows that the composite reliability (CR) values are ranging from 0.877 to 0.927 and Cronbach $(\alpha)$ values from 0.877 to 0.926 where rho_A shows 0.881 to 0.928 . Scholars have given the rule of thumb for outer loading of each item should be higher than 0.5 as conferred by Hair et al. (2006). Although loading of more than 0.7 reflects more variance. Figure 2 shows the loadings for each indicator are way higher than 0.7 , ranging from 0.751 to 0.924 which indicates good loading. The given threshold for the AVE value is equal to or above 0.50, is appropriate (Hair et al., 2013). Thus, AVE for this current study is ranging from 0.678 to 0.760 . The test result in the current study shows the good reliability which confirms that the measurement model maintained sufficient convergent validity.

Fornell and Larcker (1981) mentioned, to show discriminat legitimacy, the square root of the AVE of each construct should always be higher than the construct's correlation with other latent variables. Hence, the current study In Table 4, the results are also reported good discriminating validity of the measuring model. Besides, cross-loading of all items has been examined and the result indicated the loadings of each construct represent the higher value of each item within the constructs. The distinctness of the construction is concentrated with discriminating validity of the phenomenon taken by a construct is unique and not the other constructs represented in the framework (Hair et al., 2013).

Discriminatory validity is assessed using Fornel-Larcker and Heterotrait Monotrait Ratio of correlations (HTMT) by assessing the cross-loaded accusing of constructs. Initially, to accomplish discriminant validity, construction loadings shall be high on themselves and low on other constructs (Vinzi et al., 2010). Table 4 shows the good discriminant validity as it illustrates the square AVE of each factor is larger than any of its correlations with the other factors. Thus, the result of this study shows acceptable discriminant validity of each construct.

Tables 4 Construct Reliability and Convergent Validity

\begin{tabular}{|l|c|c|c|c|c|c|c|c|c|c|}
\hline Variables & $\boldsymbol{\alpha}$ & rho_A & CR & AVE & AS & CSAT & EMP & RL & RES & TAN \\
\hline Assurance (AS) & $\mathbf{0 . 9 2 6}$ & $\mathbf{0 . 9 2 8}$ & $\mathbf{0 . 9 2 7}$ & $\mathbf{0 . 7 6 0}$ & $\mathbf{0 . 8 7 2}$ & & & & & \\
\hline Customer Satisfaction (CSAT) & $\mathbf{0 . 8 9 3}$ & $\mathbf{0 . 8 9 7}$ & $\mathbf{0 . 8 9 3}$ & $\mathbf{0 . 6 7 8}$ & 0.618 & $\mathbf{0 . 8 2 3}$ & & & & \\
\hline Empathy (EMP) & $\mathbf{0 . 8 9 3}$ & $\mathbf{0 . 8 9 5}$ & $\mathbf{0 . 8 9 3}$ & $\mathbf{0 . 7 3 6}$ & 0.329 & 0.354 & $\mathbf{0 . 8 5 8}$ & & & \\
\hline Reliability (RL) & $\mathbf{0 . 8 8 2}$ & $\mathbf{0 . 8 8 9}$ & $\mathbf{0 . 8 8 2}$ & $\mathbf{0 . 7 1 5}$ & 0.559 & 0.559 & 0.386 & $\mathbf{0 . 8 4 6}$ & & \\
\hline Responsiveness (RES) & $\mathbf{0 . 8 9 6}$ & $\mathbf{0 . 8 9 8}$ & $\mathbf{0 . 8 9 6}$ & $\mathbf{0 . 6 8 2}$ & 0.754 & 0.595 & 0.457 & 0.562 & $\mathbf{0 . 8 2 6}$ & \\
\hline Tangibility (TAN) & $\mathbf{0 . 8 7 7}$ & $\mathbf{0 . 8 8 1}$ & $\mathbf{0 . 8 7 7}$ & $\mathbf{0 . 7 0 5}$ & 0.303 & 0.589 & 0.575 & 0.356 & 0.280 & $\mathbf{0 . 8 3 9}$ \\
\hline
\end{tabular}

\section{Structural Model}

The structural model reflects the relationship between the constructs or the latent variables that were hypothesized in this study.

Collinearity issue of structured model: VIF values of all the constructs assess collinearity issues in structured model. According to the scholars Kock (2015), the common method bias (VIF) value should be lower or equal to 5. The VIF values for this study are between 1.958 to 3.924 and none of the vales exceed threshold value.

Coefficient of determination $\left(\mathbf{R}^{2}\right)$ : $\mathrm{R}^{2}$ represents the variance in the independent variable by independent constructs (Elliott and Woodward, 2007). Both path coefficients and $\mathrm{R}^{2}$ score were determined by the structural model analysis. According to Hair et al. (2017), $\mathrm{R}^{2}$ values of $0.75,0.50$ and 0.25 which describes substantial, moderate, and weak levels of predictive accuracy. The t-value $>1.96$ is significant at $\mathrm{p}<0.05$ and t-value $>2.58$ is significant at $\mathrm{p}<0.01$ (Hair et al., 2017). So, Figure 2 shows the $\mathrm{R}^{2}$ value in this model is $62.40 \%$ for Customer Satisfaction which indicates moderate level of predictive accuracy.

The Predictive Relevance $\left(\mathbf{Q}^{2}\right)$ Effect Sizes: The size of the effect of latent variables was assessed through crossvalidated redundancy $\mathrm{Q}^{2}$ Henseler et al. (2009). The predictive relevance that exists in the model of the value of $\mathrm{Q}^{2}$ is higher than zero is considered as the existence of predictive relevance in the model Chin (1998). The present study met the rule of thumb (Table 5). 
The effect Sizes $\mathbf{F}^{2}$ : in the present study, all the values of $F^{2}$ are higher than 0.02. By following Chin (1998) suggestion, effect size can be calculated as:

$$
\mathbf{f}^{2}=\left(\mathbf{R}_{\text {included }}^{2}-\mathbf{R}^{2} \text { excluded }\right) / 2
$$

This study met the rule of thumb (Table 5).

Table 5 Structured Model Results

\begin{tabular}{|l|c|c|c|c|}
\hline \multicolumn{1}{|c|}{ Construct } & $\begin{array}{c}\text { Common method } \\
\text { bias (VIF) }\end{array}$ & $\begin{array}{c}\text { f square } \\
\left(\mathbf{F}^{\mathbf{2}}\right)\end{array}$ & $\begin{array}{c}\mathbf{Q} \text { square }\left(\mathbf{Q}^{2}\right) \\
\text { Customer Satisfaction }\end{array}$ \\
\hline Tangibility & 1.585 & 0.412 & & \\
\cline { 1 - 3 } Reliability & 1.652 & 0.051 & & \\
\cline { 1 - 3 } Responsiveness & 2.774 & 0.075 & \multirow{2}{*}{$\mathbf{0 . 3 6 4}$} & \multirow{2}{*}{$\mathbf{0 . 6 2 4}$} \\
\hline Assurance & 2.540 & 0.052 & & \\
\hline Empathy & 1.782 & 0.061 & & \\
\hline
\end{tabular}

\section{Model Fit}

Though the NFI value is just below the 0.9 but by considering all other threshold including the result of SRMR and Chi-Square it can be reported that the proposed model may consider as fit.

Table 6. Model Fit

\begin{tabular}{|l|l|l|}
\hline Fit Indices & Estimated Model & Ideal Threshold \\
\hline SRMR & 0.044 & $<0.08$ \\
\hline Chi-Square & 449.493 & Upper is better \\
\hline NFI & 0.883 & $>0.9$ \\
\hline
\end{tabular}

Table 7. Result of Proposed Model

\begin{tabular}{|l|l|l|l|l|l|}
\hline Hypothesis & Path & $\boldsymbol{\beta}$ & T-Stats & $\mathbf{P}_{\text {-Values }}$ & Decision \\
\hline $\mathrm{H}_{1}$ & Tan --->CSAT & 0.495 & 5.889 & 0.000 & Accepted \\
\hline $\mathrm{H}_{2}$ & RL --->CSAT & 0.178 & 2.257 & 0.024 & Accepted \\
\hline $\mathrm{H}_{3}$ & RES --->CSAT & 0.280 & 2.545 & 0.010 & Accepted \\
\hline $\mathrm{H}_{4}$ & AS --->CSAT & 0.224 & 2.160 & 0.034 & Accepted \\
\hline $\mathrm{H}_{5}$ & EM --->CSAT & -0.201 & 2.361 & 0.017 & Accepted \\
\hline
\end{tabular}

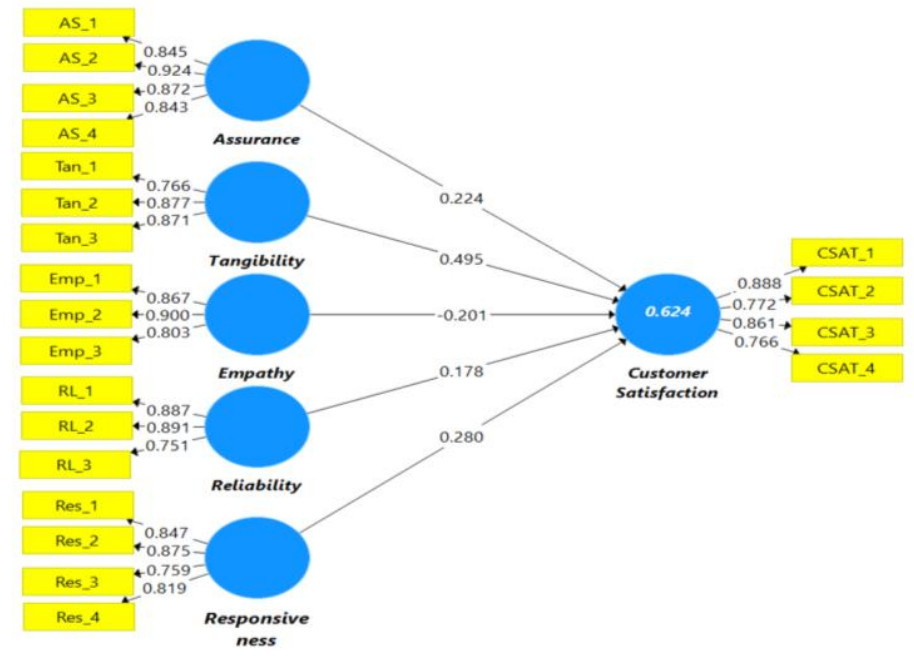

Figure 2. Path analysis, Outer loading, and R square

\section{Hypothesis Testing}

Figure 2 and Table 7 illustrates the path coefficient $(\beta), t$-statistics and $p$-value of each hypothesis. Based on the analysis all the hypotheses are found to be significant thus supported. $H_{l}(\beta=0.495, \mathrm{t}=5.889)$ indicates the path between Tangibility and Marin tourism customer satisfaction, indicating the positive and significant relationship between TAN and CSAT. $H_{2}(\beta=0.178, \mathrm{t}=2.257)$ shows the path between Reliability and Marin tourism customer satisfaction; and found significant and positive relationship between RL and CSAT. $H_{3}(\beta=0.280, \mathrm{t}=2.545)$ demonstrates the positive relationship between Responsiveness and Marin tourism customer satisfaction. $H_{4}(\beta=0.224, \mathrm{t}=2.160)$ explains that Assurance has a positive and significant influence on Marin tourism customer satisfaction. $H_{5}(\beta=-0.201, \mathrm{t}=2.361)$ prescribed the significant and negative relationship between Empathy and Marin tourism customer satisfaction.

\section{Discussion and practical implementations}

Based on facts analyses, essential outcomes are obtained for all proportions of service quality, namely, tangible, accurate, reliable, assured, and empathic expectations and impacts on marine tourism customer service. The study also found this to be true for the marine tourism facilities in Malaysia, particularly observation from the Klang Valley respondent. Along with, travel operators should also meet marine tourism standards of all types of amenities previously listed. Moreover, the various types of services demonstrated varying views of marine tourism customer in every determinant of the SERVQUAL dimensions efficiency, as revealed by the ratio of the analysis. These results indicate that the Klang Valley tour operating companies are more focused on developing these sorts of service. In order to ensure the positive experience of visitors, a high level of empathy, care and consideration are necessary. Security and safety are also a concern which needs to be dealt with. For all journeys into Malaysia's several marine tourisms destinations, safety laws and guidelines should be followed. This is particularly true for coastal entertainment workers like surfing, paragliding, snorkelling, and diving. Guidelines including the use of life jackets on such water diving should therefore be enforced.

Tourism - related coordination and safety briefing by the service provider on sightseeing trips such as marine sports and entertainment will allow visitors to avoid incidents that might ruin a wonderful moment. These activities build a feeling of assurance and believe for tourists who visit the marine tourist destination. An important outcome has been identified in comparison to the entire satisfaction of tourists in the marine tourism segment. This demonstrates that the degree of tourist satisfaction is a crucial indicator of service quality assessment. To assure that a moderate degree of satisfaction between visitors is retained, and staff training is among the strategies that marine tourism service providers should follow. Certain aspects that can be evaluated in further marine tourism studies, in addition to the component that are significant for safety, Security, policy and communication strategies. Additionally, involvement from marine tourism customers satisfaction should be continuously and regularly assessed since consumer expectations and desires evolve over time.

\section{Conclusion and Future research}

This research has extensive experience in designing an expanded service quality model. Mostly on justification of the survey results, the suggestions in this paper would enable the marine tourism service provider to sustain their quality-of- 
service programs in order to enhance the tourism sector in Malaysia. In addition, the reviews are hoped to direct other segments of tourism on how to strengthen quality of service especially for tourists. Nevertheless, the analysis including its results of the survey had been frequently checked and given the restricted sample scale and scope. In future research, a wider sample size with social media impact can be investigate. Such key points (e.g., governmental regulations, visitor expectations, etc.) and their degree of customer satisfaction in maritime tourism must be addressed in further research.

\section{REFERENCE}

Athanassopoulos, A., Gounaris, S., \& Stathakopoulos, V. (2001). Behavioural responses to customer satisfaction: an empirical study. European journal of marketing, 35(5), 687-707. https://doi.org/10.1108/03090560110388169

Allred, A.T., \& Addams, H.L. (2000). Service quality at banks and credit unions: what do their customers say? International Journal of Bank Marketing, 18(4), 200-207. https://doi.org/10.1108/09604520010307049

Anderson, E., \& Fornell, C. (1994). A customer satisfaction research prospectus. In R. T. Rust, \& R. L. Oliver (Eds.), Service quality: New directions in theory and practice, 241-268. SAGE Publications, Inc. https://www.doi.org/10.4135/9781452229102.n11

Augustyn, M., \& Ho, S. K. (1998). Service quality and tourism. Journal of travel research, 37(1), 71-75. https://doi.org/ $10.1177 / 004728759803700110$

Bartlett, J.E., \& Han, F. (2007). Analysis of service quality in restaurants in China: An eastern perspective. In ABR \& TLC Conference Proceedings.

Berry, L.L., Parasuraman, A., \& Zeithaml, V.A. (1994). Alternative scales for measuring service quality: A comparative assessment based on psychometric and diagnostic criteria. Journal of Retailing, 70(3), 201-230. https://doi.org/10.1016/0022-4359(94)90033-7

Bhuiyan, A.H., Darda, A., \& Habib, W. (2020). Marine Tourism for Sustainable Development in Cox's Bazar, Bangladesh. http://hdl.handle.net/11540/12113

Bin, L.C., Salleh, N.H.M., \& Bin, L.K. (2020). The Evaluation Model for Coral Reef Restoration from Management Perspective for Ensuring Marine Tourism Sustainability. Journal of Sustainability Science and Management, 15(1), 93-104.

Brown, V. (2013). Top 10 Malaysian islands getaways, The Star Online. http://www.thestar.com.my/News/Nation/2013/11/21/Top-10Malaysian-island-getaways/

Cao, J. (2020). The Development of Marine Tourism based on Resource Market and Product. Journal of Coastal Research, 107(SI), 109112. https://doi.org/10.2112/JCR-SI107-028.1

Chin, W.W. (1998). The partial least squares approach to structural equation modeling. Modern methods for business research, 295(2), 295-336. http://doi.org/10.4236/psych.2012.38085

Daskalakis, N.G., \& Stathopoulos, A. (2008). Users' perceptive evolution of bus arrival time deviations in Stochastic Networks. Journal of Public Transportation, 11(4), 25-38. http://doi.org/10.5038/2375-0901.11.4.2

Elliott, A.C., \& Woodward, W.A. (2007). Statistical analysis quick reference guidebook: With SPSS examples. Sage Publications, 85-93. https://bit.ly/3fDMq23

Fornell, C., \& Larcker, D.F. (1981). Evaluating structural equation models with unobservable variables and measurement error. Journal of marketing research, 18(1), 39-50. https://doi.org/10.1177/002224378101800104

Gounaris, S., \& Dimitriadis, S. (2003). Assessing service quality on the web: evidence from business-to-consumer portals. Journal of Services Marketing, 7(5), 529-548. https://doi.org/10.1108/08876040310486302

Hair, Jr.J.F., Sarstedt, M., Ringle, C.M., \& Gudergan, S.P. (2017). Advanced issues in partial least squares structural equation modeling. Sage Publications, 73-74. https://bit.ly/3hOON54

Hair, B., Babin, A., \& Tatham (2006). Multivariate data analysis. Aufl. Upper Saddle River, NJ.

Hair, J.F., Ringle, C.M., \& Sarstedt, M. (2013). Partial least squares structural equation modeling: Rigorous applications, better results and higher acceptance. Long range planning, 46(1-2), 1-12. https://doi.org/10.1016/j.lrp.2013.01.001

Hall, C. (2001). Trends in ocean and coastal tourism: the end ofthe last frontier? Ocean \& Coastal Management, 44(9-10), 601-618. https://doi.org/10.1016/S0964-5691(01)00071-0

Henseler, J., Ringle, C.M., \& Sinkovics, R.R. (2009). The use of partial least squares path modeling in international marketing. In New challenges to international marketing. Emerald Group Publishing Limited. https://doi.org/10.1108/S1474-7979(2009)0000020014

Hoyle, R.H. (1995). The structural equation modeling approach: Basic concepts and fundamental issues. In R. H. Hoyle (Ed.), Structural equation modeling: Concepts, issues, and applications. 1-15. Sage Publications, Inc. https://cutt.ly/kbISPQM

Ibrahim, J.A., \& Ahmad, M.Z. (2008). Pelancongan Negeri Kedah Darul Aman: Isudan Cabaran. Persidangan Kebangsan Ekonomi Malaysia Ke Iii (Perkem Iii), 1, 191-202. http://repo.uum.edu.my/id/eprint/7111

Iacobucci, D. (2010). Structural equations modeling: Fit indices, sample size, and advanced topics. Journal of consumer psychology, 20(1), 90-98. https://doi.org/10.1016/j.jcps.2009.09.003

Jones, T.E., \& Syura, N.B. (2020). Chapter 5 - Searching for sustainable tourism in Malaysia. In Dolezal, Trupp \& Bui (eds.) Tourism and Development in Southeast Asia. Routledge, 73-87. https://bit.ly/3fanmAK

Kock, N. (2015). Common method bias in PLS-SEM: A full collinearity assessment approach. International Journal of e-Collaboration (ijec), 11(4), 1-10. https://www.igi-global.com/article/common-method-bias-in-pls-sem/132843

Lam-González, Y.E., León, C.J., \& León, J.D. (2019). Coopetition in Maritime Tourism: Assessing the Effect of Previous Islands' Choice and Experience in Tourist Satisfaction. Sustainability, 11(22), 6334. https://doi.org/10.3390/su11226334

Latif, K., \& IIM, N.S. (2015). The Impact of Tourism Service Quality on Satisfaction. Int. Journal of Economics and Management, 9(s), 67 - 94. http://www.econ.upm.edu.my/ijem

Ostheimer, S. (2012). 10 best islands for a Malaysia holiday, CNN. http://travel.cnn.com/explorations/escape/islandhopping-malaysia-334981

Owen, B., Malkovich, P., \& Malkovich, C. (1995). Understanding the Value of ISO 9000: A Management Guide to Higher Quality, Productivity, and Sales. SPC Press.

Papageorgiou, M. (2016). Coastal and marine tourism: A challenging factor in Marine Spatial Planning. Ocean \& Coastal Management, 129, 44-48. https://doi.org/10.1016/j.ocecoaman.2016.05.006

Parasuraman, A., Zeithaml, V.A., \& Berry, L.L. (1985). A conceptual model of service quality and its implications for future research. Journal of marketing, 49(4), 41-50. https://doi.org/10.1177/002224298504900403 
Parasuraman, A., Zeithaml, V.A., \& Berry, L.L. (1988). SERVQUAL: A Multiple-item scale for measuring consumer perception of service quality. Journal of Retailing, 64, 12-40. https://bit.ly/3ewIYqU

Pawitra, T., \& Tan, K. (2003). Tourist satisfaction in Singapore - a perspective from Indonesian tourists. Managing Service Quality: An International Journal, 13(5), 399-411. https://doi.org/10.1108/09604520310495868

Rogerson, C.M. (2020). Coastal and Marine Tourism in The Indian Ocean Rim Association States: Overview and Policy Challenges. GeoJournal of Tourism and Geosites, 29 (2), 715-731. https://doi.org/10.30892/gtg.29226-501

Rogerson, C.M., Benkenstein, A., \& Mwongera, N. (2018). Coastal Tourism and Economic Inclusion in Indian Ocean Rim Association States. African Portal: https://www.africaportal.org/publications/coastal-tourism-and-economic-inclusion-indian-ocean-rim-association-states/

Santos, J. (2002). From intangibility to tangibility on service quality perceptions: a comparison study between consumers and service providers in four service industries. Managing Service Quality, 12(5), 292-302. https://doi.org/10.1108/09604520210442083

Sureshchandar, G., Rajendran, C., \& Kamalanabhan, T. (2002). Customer Perceptions of Service Quality: A Critique. Total Quality Management, 12(1), 111-124. https://doi.org/10.1080/09544120020010138

Tse, D.K., \& Wilton, P.C. (1988). Models of Consumer Satisfaction Formation: An Extension. Journal of Marketing Research, 25(2), 204-212. https://doi.org/10.1177/002224378802500209

Varca, P.E. (2004). Service skills for service workers: emotional intelligence and beyond. Managing Services Quality: An International Journal, 14(6), 457-467. https://doi.org/10.1108/09604520410569793

Vinzi, V.E., Trinchera, L., \& Amato, S. (2010). PLS Path Modeling: From Foundations to Recent Developments and Open Issues for Model Assessment and Improvement. In: Esposito Vinzi V., Chin W., Henseler J., Wang H. (eds) Handbook of Partial Least Squares. Springer Handbooks of Computational Statistics. Springer, Berlin, Heidelberg. https://doi.org/10.1007/978-3-540-32827-8_3

Vogel, M., \& Pettinari, J. (2002). Personal Safety and Transit: Paths, Environments, Stops and Stations, Cts 02-05. https://ntlrepository.blob.core.windows.net/lib/19000/19500/19573/PB2002107962.pdf

Western Mediterranean Ecoregion. (2019). Coastal and Maritime Tourism. Retrieved from MED Maritime Integreted Projects: http://www.medmaritimeprojects.eu/download/ProjectMediamer/Factsheets/WM_Tourism_factsheet_080415.pdf

Wonderful Malaysia (2014). 10 best dive locations in Malaysia. Retrieved January 7, 2014, from http://www.wonderfulmalaysia.com/ faq/10-best-dive-locations-in-malaysia.htm

Zakaria, Z., Hamid, A.C., Karim, Z.A., \& Daud, N.M. (2010). Tourists' Expectations and Perceptions on the Service Quality in Malaysian Tourism Industry. Global Business and Management Research: An International Journal, 1(3), 69.

Zhi-Gang, Y., \& Xiao-Dong, D. (2013). Measuring passenger's perceptions of taxi service quality with weighted SERVPERF: A case of Hangzhou, China. Paper presented at Jinan Conference [Online], Shanxi China.

Article history: Received: 29.01.2021 Revised: 06.05.2021 Accepted: 18.08.2021 Available online: 07.09.2021 